\title{
EXTRACTION AND RELEASE OF INDIVIDUAL FREE FATTY ACIDS BY THE HEART AND FAT DEPOTS *
}

\author{
By MARTIN E. ROTHLIN † AND RICHARD J. BING \\ (From the Department of Medicine, Wayne State University College of Medicine, \\ Detroit, Mich.)
}

(Submitted for publication January 19, 1961 ; accepted April 7, 1961)

It has previously been demonstrated (1) that in the postabsorptive state energy production of the heart depends largely on fatty acid metabolism; both esterified and nonesterified or free fatty acids (FFA) are taken up by the heart muscle. Although the general turnover rate of individual FFA has been studied, no investigations have been undertaken to discover their fate in the heart muscle.

After administration of $\mathrm{C}^{\mathbf{1 4}}$-labeled palmitic, oleic or linoleic acid which had been bound to albumin in vitro, Fredrickson and Gordon (2) found no difference in fractional turnover rate of these individual FFA in the plasma of the intact subject. General conclusions from these observations are difficult, since Bates and Olson (3) have pointed out that in the animal organism the fate of fatty acids bound to albumin in vitro may be different from that of endogenous FFA.

The present study deals with the myocardial extraction of individual FFA. Since, in the course of this investigation, it was found that the rate of myocardial uptake of individual FFA differed, the work was extended to include the release of individual FFA by adipose tissue.

\section{METHODS}

The patients studied in this report were free of metabolic disorders, and none of them was in congestive heart failure. Food was withheld for 12 hours prior to the test. For the animal studies, mongrel dogs were used from which food was withheld for at least 16 hours prior to the experiment. The dogs were anesthetized with pen-

* Work supported by U. S. Public Health Service Grant no. H-5043, The American Heart Association, The Michigan Heart Association, Life Insurance Medical Research Fund, Tobacco Industry Research Committee, Abbott Laboratories, and the Burroughs Wellcome Fund. Presented in part before the Central Society for Clinical Investigation, Chicago, I1l., 1960.

$\dagger$ Fellow of the Foundation for Biol.-Med. Research (Switzerland). tobarbital (30 $\mathrm{mg}$ per $\mathrm{kg}$ intravenously). Coronary venous blood of man and dog was obtained by catheterization of the coronary sinus (4). Simultaneously, arterial blood was collected through an indwelling needle from the brachial artery (man) or from the femoral artery $(\mathrm{dog})$. Blood from the saphenous vein ( $\mathrm{dog})$, which drains largely subcutaneous adipose tissue, was collected from a needle inserted into this vessel.

Free fatty acids were determined with the technique of Gordon, Cherkes and Gates (5). For gas chromatography, the FFA were extracted with 90 per cent ethanolwater containing 0.2 per cent $\mathrm{NaOH}$ from the iso-octane extract prepared during this procedure. After removing the contaminating esters from this alkaline ethanol-water phase by petroleum ether extraction, the ethanol-water phase was acidified and the FFA extracted with light petroleum. The solvent was then evaporated and the FFA converted into methyl esters according to the method used by Hallgren, Stenhagen, Svanborg and Svennerholm (6). Analytical separation was carried out on a Barber Colman gas chromatograph, model 10, provided with an argon ionization detector (7). Ethylene glycol succinate polyester was used as stationary phase at a temperature of $179^{\circ}$ or $182^{\circ} \mathrm{C}(8)$. FFA peaks were identified by comparison of their retention times with those of known standard fatty acids. Peak areas were measured by triangulation and by electronic integration. On each sample, three chromatograms were performed and evaluated by both methods. Since small arteriovenous differences of the FFA composition were involved in these observations, the reproducibility of the method had to be ascertained. Ten successive gas chromatographic analyses of a standard mixture of known composition were therefore performed. As in the remainder of the experiments, peak areas were determined both by triangulation and electronic integration. Table I represents the mean value, maximum deviations and variation coefficient for each component. It may be seen that the variation coefficients of the recoveries are below 1 per cent with the exception of palmitoleate. Table II illustrates the reproducibility of the applied method. Four aliquots of the same dog plasma were analyzed for their FFA composition. On each sample, as in the remainder of the experiments, three chromatograms were performed. The determinations were all within 0.7 per cent.

According to Lovelock (7), the mass sensitivity of the ionization detector (i.e., the response of the detector to a given mass of substance) is constant, within the 
TABLE I

Fatty acid composition of a standard mixture analyzed by ten gas chromatograms

\begin{tabular}{lccccc}
\hline \hline & Palmitate & Palmitoleate & Stearate & Oleate & Linoleate \\
\hline Weighed & $\%$ & $\%$ & $\%$ & $\%$ & $\%$ \\
$\begin{array}{c}\text { Mean of } \\
\text { recoveries }\end{array}$ & 25.2 & 7.8 & 19.8 & 28.6 & 18.6 \\
$\begin{array}{c}\text { Range of } \\
\text { recoveries }\end{array}$ & 27.8 & 7.1 & 18.0 & 29.7 & 17.4 \\
$\begin{array}{c}\text { Variation co- } \\
\text { efficient of } \\
\text { recoveries }\end{array}$ & 0.96 & 1.67 & 0.59 & 0.53 & 0.71 \\
\hline
\end{tabular}

limits of precision of the method, for the methyl esters of the higher fatty acids. The FFA composition, analyzed by gas chromatography, is therefore expressed in per cent by weight of the sum of the methyl esters of palmitic, palmitoleic, stearic, oleic and linoleic acids (Tables I, II, III, IV and V). According to Dole and co-workers (9), these fatty acids are the main components of FFA and comprise about 85 per cent of this plasma lipid fraction in man. Several fatty acids of a chain length of 6 to $14 \mathrm{C}$-atoms, as well as higher unsaturated fatty acids with 18 and $20 \mathrm{C}$-atoms, contribute the remaining 15 per cent to the total FFA; these were not determined. Since, therefore, only 85 per cent of the plasma FFA was analyzed, these calculated values are too high and must be corrected to afford a comparison with other published data. Consequently, Table III contains not only the experimentally determined values but also the mean values calculated on the basis that only 85 per cent of the total FFA was determined.

Total FFA levels represent the amount of FFA in plasma expressed in milliequivalents per $100 \mathrm{ml}$. Individual FFA levels were calculated from total FFA levels and the composition of FFA. The percentage by weight in which the composition of individual FFA is given was transformed into moles per cent. Eighty-five per cent of the total FFA levels determined by titration was used as the sum of the combined individual FFA levels. Individual FFA levels were calculated as follows: $0.85 \times$ total FFA ( $\mathrm{mEq} / 100 \mathrm{ml}$ plasma) $\times$ concentration of individual FFA (mole fraction). The percentage myocardial extraction of total or individual FFA was calculated as follows: (a.FFA - c.s.FFA) $\times 100 /$ a.FFA, where a.FFA represents total or individual FFA level in milliequivalents per $100 \mathrm{ml}$ arterial plasma, and c.s.FFA represents total or individual FFA level in milliequivalents per $100 \mathrm{ml}$ coronary sinus plasma. The percentage release of total or individual FFA by adipose tissue was calculated with the formula: (s.v.FFA - a.FFA) $\times 100$ / s.v.FFA, where s.v.FFA represents total or individual FFA level in milliequivalents per $100 \mathrm{ml}$ of saphenous vein plasma, and a.FFA represents total or individual FFA level in milliequivalents per $100 \mathrm{ml}$ arterial plasma. As outlined above, it was assumed in these calculations that the FFA not determined comprise the same percentage in arterial and coronary sinus blood (15 per cent). It must be considered that the proportion of these com- ponents in coronary sinus blood could differ from that in arterial blood. This, however, would not affect the observation that the percentage extraction or the percentage release of an individual FFA is different from that of another, but it would affect the absolute estimates of extraction and release of individual FFA.

\section{RESULTS}

Myocardial extraction of individual FFA. Table III illustrates the arterial and coronary sinus levels of total FFA in fasting patients. The mean arterial FFA level found was $0.0692 \mathrm{mEq}$ per $100 \mathrm{ml}$ with a range of from 0.0368 to 0.1227 $\mathrm{mEq}$ per $100 \mathrm{ml}$ plasma. The mean FFA level in coronary sinus blood was $0.0509 \mathrm{mEq}$ per 100 $\mathrm{ml}$ plasma with a range of from 0.0281 to 0.0931 $\mathrm{mEq}$ per $100 \mathrm{ml}$ plasma. Table IV illustrates the results obtained in dogs. The mean arterial FFA level was 0.0328 and that in the coronary sinus 0.0155 . The difference between values obtained in patients and in dogs may have been the result of pentobarbital anesthesia used in the animals (10).

Data on the composition of FFA in arterial and coronary sinus blood are illustrated in Tables III and IV. Oleic acid was the largest component in man and in dog (50.0 and 44.2 per cent, respec-

TABLE II

Gas chromatographic analysis of the FFA composition of four samples of the same dog plasma

\begin{tabular}{cccccc}
\hline \hline & \multicolumn{5}{c}{ FFA composition* } \\
\cline { 2 - 6 } Sample no. & $\begin{array}{c}\text { Palmitic } \\
\text { acid }\end{array}$ & $\begin{array}{c}\text { Palmitoleic } \\
\text { acid }\end{array}$ & $\begin{array}{c}\text { Stearic } \\
\text { acid }\end{array}$ & $\begin{array}{c}\text { Oleic } \\
\text { acid }\end{array}$ & $\begin{array}{c}\text { Linoleic } \\
\text { acid }\end{array}$ \\
\hline & $\% \%$ & $\%$ & $\%$ & $\%$ & $\%$ \\
1 & 27.5 & 3.0 & 15.1 & 41.4 & 13.0 \\
2 & 27.2 & 2.9 & 15.0 & 41.8 & 13.1 \\
3 & 27.7 & 2.9 & 15.7 & 41.2 & 12.5 \\
4 & 27.8 & 2.9 & 15.6 & 41.3 & 12.4 \\
\hline
\end{tabular}

* Expressed in per cent by weight of the sum of the methyl esters of the 5 determined fatty acids. 
TABLE III

Coronary arteriovenous difference of FFA level and composition in man

\begin{tabular}{|c|c|c|c|c|c|c|c|}
\hline \multirow[b]{2}{*}{$\begin{array}{l}\text { Patient } \\
\text { no. }\end{array}$} & & \multirow[b]{2}{*}{ FFA levels } & \multicolumn{5}{|c|}{ FFA composition* } \\
\hline & & & $\underset{\text { acid }}{\text { Palmitic }}$ & $\underset{\text { acid }}{\text { Palmitoleic }}$ & $\begin{array}{l}\text { Stearic } \\
\text { acid }\end{array}$ & $\begin{array}{l}\text { Oleic } \\
\text { acid }\end{array}$ & $\begin{array}{c}\text { Linoleic } \\
\text { acid }\end{array}$ \\
\hline 1 & $\begin{array}{l}\text { A } \dagger \\
\text { CS } \dagger\end{array}$ & $\begin{array}{c}m E q / 100 m l \\
\text { plasma } \\
0.0550 \\
0.0414\end{array}$ & $\begin{array}{c}\% \\
28.6 \\
30.0\end{array}$ & $\begin{array}{l}\% \\
2.7 \\
2.7\end{array}$ & $\begin{array}{c}\% \\
10.0 \\
10.4\end{array}$ & $\begin{array}{c}\% \\
48.0 \\
45.4\end{array}$ & $\begin{array}{c}\% \\
10.7 \\
11.5\end{array}$ \\
\hline 2 & $\stackrel{\mathrm{A}}{\mathrm{CS}}$ & $\begin{array}{l}0.0519 \\
0.0403\end{array}$ & $\begin{array}{l}28.5 \\
33.0\end{array}$ & $\begin{array}{l}2.7 \\
2.4\end{array}$ & $\begin{array}{l}10.2 \\
10.7\end{array}$ & $\begin{array}{l}46.8 \\
42.3\end{array}$ & $\begin{array}{l}11.8 \\
11.7\end{array}$ \\
\hline 3 & $\begin{array}{l}\mathrm{A} \\
\mathrm{CS}\end{array}$ & $\begin{array}{l}0.0582 \\
0.0426\end{array}$ & $\begin{array}{l}26.1 \\
34.0\end{array}$ & $\begin{array}{l}2.7 \\
4.6\end{array}$ & $\begin{array}{l}11.4 \\
14.0\end{array}$ & $\begin{array}{l}52.0 \\
39.8\end{array}$ & $\begin{array}{l}7.8 \\
7.6\end{array}$ \\
\hline 4 & $\begin{array}{l}\mathrm{A} \\
\mathrm{CS}\end{array}$ & $\begin{array}{l}0.0764 \\
0.0561\end{array}$ & $\begin{array}{l}28.7 \\
31.6\end{array}$ & $\begin{array}{l}4.0 \\
3.6\end{array}$ & $\begin{array}{l}8.9 \\
9.5\end{array}$ & $\begin{array}{l}52.5 \\
49.4\end{array}$ & $\begin{array}{l}5.9 \\
5.9\end{array}$ \\
\hline 5 & $\begin{array}{l}\mathrm{A} \\
\mathrm{CS}\end{array}$ & $\begin{array}{l}0.1227 \\
0.0931\end{array}$ & $\begin{array}{l}26.9 \\
28.1\end{array}$ & $\begin{array}{l}3.8 \\
3.8\end{array}$ & $\begin{array}{l}5.9 \\
6.1\end{array}$ & $\begin{array}{l}52.9 \\
50.8\end{array}$ & $\begin{array}{l}10.5 \\
11.2\end{array}$ \\
\hline 6 & $\stackrel{\mathrm{A}}{\mathrm{CS}}$ & $\begin{array}{l}0.0368 \\
0.0281\end{array}$ & $\begin{array}{l}30.0 \\
33.7\end{array}$ & $\begin{array}{l}3.5 \\
3.7\end{array}$ & $\begin{array}{l}11.6 \\
10.4\end{array}$ & $\begin{array}{l}47.5 \\
44.7\end{array}$ & $\begin{array}{l}7.4 \\
7.5\end{array}$ \\
\hline 7 & $\stackrel{\mathrm{A}}{\mathrm{CS}}$ & $\begin{array}{l}0.0834 \\
0.0545\end{array}$ & $\begin{array}{l}29.2 \\
31.7\end{array}$ & $\begin{array}{l}2.8 \\
2.9\end{array}$ & $\begin{array}{l}8.4 \\
9.7\end{array}$ & $\begin{array}{l}50.6 \\
46.2\end{array}$ & $\begin{array}{l}9.0 \\
9.5\end{array}$ \\
\hline \multirow[t]{2}{*}{ Mean } & A & 0.0692 & $\begin{array}{l}28.3 \\
24.0 \ddagger\end{array}$ & $\begin{array}{l}3.2 \\
2.7\end{array}$ & $\begin{array}{l}9.5 \\
8.1\end{array}$ & $\begin{array}{l}50.0 \\
42.5\end{array}$ & $\begin{array}{l}9.0 \\
7.7\end{array}$ \\
\hline & $\mathrm{CS}$ & 0.0509 & $\begin{array}{l}31.7 \\
26.9 \ddagger\end{array}$ & $\begin{array}{l}3.4 \\
2.9\end{array}$ & $\begin{array}{r}10.1 \\
8.6\end{array}$ & $\begin{array}{l}45.5 \\
38.7\end{array}$ & $\begin{array}{l}9.3 \\
7.9\end{array}$ \\
\hline
\end{tabular}

* Expressed in per cent by weight of the sum of the methyl esters of the 5 determined fatty acids.

$\dagger \mathrm{A}=$ arterial; $\mathrm{CS}=$ coronary sinus.

$\ddagger$ Corrected values; see text under Methods.

TABLE IV

Coronary arteriovenous difference of FFA level and composition in dog

\begin{tabular}{|c|c|c|c|c|c|c|c|}
\hline \multirow[b]{2}{*}{$\begin{array}{l}\text { Dog } \\
\text { no. }\end{array}$} & & \multirow[b]{2}{*}{ FFA levels } & \multicolumn{5}{|c|}{ FFA composition* } \\
\hline & & & $\underset{\text { acid }}{\text { Palmitic }}$ & $\begin{array}{c}\text { Palmitoleic } \\
\text { acid }\end{array}$ & $\begin{array}{c}\text { Stearic } \\
\text { acid }\end{array}$ & $\begin{array}{l}\text { Oleic } \\
\text { acid }\end{array}$ & $\begin{array}{c}\text { Linoleic } \\
\text { acid }\end{array}$ \\
\hline 1 & $\stackrel{\mathrm{A}}{\mathrm{CS}}$ & $\begin{array}{c}m E q / 100 m l \\
\text { plasma } \\
0.0241 \\
0.0087\end{array}$ & $\begin{array}{c}\% \\
28.7 \\
31.9\end{array}$ & $\begin{array}{l}\% \\
3.8 \\
3.4\end{array}$ & $\begin{array}{c}\% \\
15.7 \\
22.2\end{array}$ & $\begin{array}{c}\% \\
39.6 \\
27.7\end{array}$ & $\begin{array}{c}\% \\
12.2 \\
15.1\end{array}$ \\
\hline 2 & $\begin{array}{l}\mathrm{A} \\
\mathrm{CS}\end{array}$ & $\begin{array}{l}0.0530 \\
0.0276\end{array}$ & $\begin{array}{l}22.7 \\
26.4\end{array}$ & $\begin{array}{l}5.2 \\
4.7\end{array}$ & $\begin{array}{r}9.5 \\
13.0\end{array}$ & $\begin{array}{l}53.9 \\
45.1\end{array}$ & $\begin{array}{r}8.8 \\
10.7\end{array}$ \\
\hline 2 & $\stackrel{\mathrm{A}}{\mathrm{CS}}$ & $\begin{array}{l}0.0476 \\
0.0169\end{array}$ & $\begin{array}{l}26.3 \\
30.8\end{array}$ & $\begin{array}{l}3.0 \\
2.6\end{array}$ & $\begin{array}{l}10.8 \\
15.6\end{array}$ & $\begin{array}{l}48.5 \\
37.6\end{array}$ & $\begin{array}{l}11.4 \\
13.3\end{array}$ \\
\hline 4 & $\stackrel{\mathrm{A}}{\mathrm{CS}}$ & $\begin{array}{l}0.0239 \\
0.0097\end{array}$ & $\begin{array}{l}29.4 \\
36.6\end{array}$ & $\begin{array}{l}3.4 \\
3.7\end{array}$ & $\begin{array}{l}14.8 \\
17.4\end{array}$ & $\begin{array}{l}44.0 \\
34.2\end{array}$ & $\begin{array}{l}8.4 \\
8.1\end{array}$ \\
\hline 5 & $\stackrel{\mathrm{A}}{\mathrm{CS}}$ & $\begin{array}{l}0.0280 \\
0.0179\end{array}$ & $\begin{array}{l}35.6 \\
39.2\end{array}$ & $\begin{array}{l}2.3 \\
2.1\end{array}$ & $\begin{array}{l}14.6 \\
15.9\end{array}$ & $\begin{array}{l}34.9 \\
31.0\end{array}$ & $\begin{array}{l}12.6 \\
11.8\end{array}$ \\
\hline 6 & $\stackrel{\mathrm{A}}{\mathrm{CS}}$ & $\begin{array}{l}0.0203 \\
0.0125\end{array}$ & $\begin{array}{l}29.8 \\
34.9\end{array}$ & $\begin{array}{l}4.0 \\
4.3\end{array}$ & $\begin{array}{l}13.6 \\
15.9\end{array}$ & $\begin{array}{l}44.0 \\
36.3\end{array}$ & $\begin{array}{l}8.6 \\
8.6\end{array}$ \\
\hline Mean & $\begin{array}{l}\mathrm{A} \\
\mathrm{CS}\end{array}$ & $\begin{array}{l}0.0328 \\
0.0155\end{array}$ & $\begin{array}{l}28.8 \\
33.3\end{array}$ & $\begin{array}{l}3.6 \\
3.5\end{array}$ & $\begin{array}{l}13.2 \\
16.7\end{array}$ & $\begin{array}{l}44.2 \\
35.3\end{array}$ & $\begin{array}{l}10.3 \\
11.3\end{array}$ \\
\hline
\end{tabular}

* Expressed in per cent by weight of the sum of the methyl esters of the 5 determined fatty acids. Abbreviations are as in Table III, 
tively, in arterial blood). The second highest was palmitic acid (28.3 per cent in man, 28.8 per cent in $\operatorname{dog}$ ). The corrected figures in Table III for arterial palmitic and palmitoleic acids were in good agreement with those reported by Dole and his associates (9). However, the fractions of stearic and linoleic acids were lower, while the proportion of oleic acid was higher in the present series.

Tables III and IV illustrate the differences between the FFA composition of arterial and coronary sinus blood. In man (Table III) the percentage of palmitic acid in coronary sinus blood was higher than that in arterial blood, while the proportion of oleic acid in coronary sinus blood was lower than in arterial blood. Both of these differences are statistically significant $(p<0.01$ and $p<0.025$, respectively). Similar results were found in dogs with the exception that stearic acid was also significantly higher in coronary sinus than in arterial blood $(\mathrm{p}<0.01)$ (Table IV).

These changes reflect a different rate of myocardial uptake of individual FFA. This is illustrated in Figure 1 in which the percentage myocardial extractions of individual FFA are outlined. Thus, the human heart extracted from arterial plasma 17.4 per cent of the free palmitic acid as compared with 32.9 per cent of the free oleic acid. The dog heart removed 37.1 per cent of the free stearic acid from arterial plasma, while 44.4 per cent of free palmitic acid and 61.1 per cent of the free oleic acid were extracted.

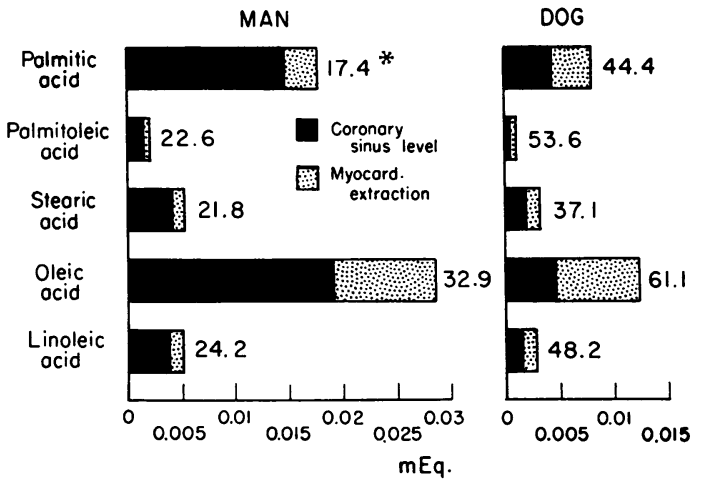

Fig. 1. Myocardial extraction of individual FFA IN MAN AND DOG. The total length of the bars represents the arterial, and the dark portion the coronary sinus level of individual FFA, expressed in $\mathrm{mEq}$ per $100 \mathrm{ml}$ plasma. The stippled portion of the bars corresponds to the myocardial extraction. Each figure* represents the percentage extraction of an individual FFA. (Mean values obtained from seven subjects and six dogs, respectively.)

Release of individual FFA from adipose tissue. Table $\mathrm{V}$ illustrates the release of individual FFA by adipose tissue of the dog. The mean total FFA level in arterial plasma was $0.0322 \mathrm{mEq}$ per $100 \mathrm{ml}$ and that of saphenous venous plasma 0.0454 $\mathrm{mEq}$ per $100 \mathrm{ml}$, illustrating release of FFA from the fat depots. Table $\mathrm{V}$ also shows that there were differences in release of individual fatty acids by the adipose tissue. For example, the proportion of oleic acid to total FFA was higher in saphenous vein blood than in arterial blood, while the reverse was the case for palmitic and stearic

TABLE V

Saphenous arteriovenous difference of FFA level and composition in dog

\begin{tabular}{|c|c|c|c|c|c|c|c|}
\hline \multirow[b]{2}{*}{$\begin{array}{l}\text { Dog } \\
\text { no. }\end{array}$} & & \multirow[b]{2}{*}{ FFA levels } & \multicolumn{5}{|c|}{ FFA composition* } \\
\hline & & & $\underset{\text { acid }}{\text { Palmitic }}$ & $\begin{array}{c}\text { Palmitoleic } \\
\text { acid }\end{array}$ & $\begin{array}{l}\text { Stearic } \\
\text { acid }\end{array}$ & $\begin{array}{l}\text { Oleic } \\
\text { acid }\end{array}$ & $\begin{array}{c}\text { Linoleic } \\
\text { acid }\end{array}$ \\
\hline 7 & $\begin{array}{l}\mathrm{A} \dagger \\
\mathrm{SV}\end{array}$ & $\begin{array}{c}m E q / 100 \mathrm{ml} \\
\text { plasma } \\
0.0370 \\
0.0570\end{array}$ & $\begin{array}{c}\% \\
31.9 \\
29.0\end{array}$ & $\begin{array}{l}\% \\
3.2 \\
4.4\end{array}$ & $\begin{array}{c}\% \\
12.1 \\
10.8\end{array}$ & $\begin{array}{c}\% \\
38.3 \\
42.2\end{array}$ & $\begin{array}{c}\% \\
14.5 \\
13.6\end{array}$ \\
\hline 8 & $\stackrel{\mathrm{A}}{\mathrm{SV}}$ & $\begin{array}{l}0.0288 \\
0.0410\end{array}$ & $\begin{array}{l}27.6 \\
27.1\end{array}$ & $\begin{array}{l}2.0 \\
2.8\end{array}$ & $\begin{array}{l}19.8 \\
17.2\end{array}$ & $\begin{array}{l}35.7 \\
39.2\end{array}$ & $\begin{array}{l}14.9 \\
13.7\end{array}$ \\
\hline 9 & $\stackrel{\mathrm{A}}{\mathrm{SV}}$ & $\begin{array}{l}0.0473 \\
0.0635\end{array}$ & $\begin{array}{l}24.7 \\
22.8\end{array}$ & $\begin{array}{l}4.5 \\
5.4\end{array}$ & $\begin{array}{l}9.7 \\
8.1\end{array}$ & $\begin{array}{l}52.5 \\
55.0\end{array}$ & $\begin{array}{l}8.6 \\
8.6\end{array}$ \\
\hline 10 & $\begin{array}{l}\mathrm{A} \\
\mathrm{SV}\end{array}$ & $\begin{array}{l}0.0157 \\
0.0199\end{array}$ & $\begin{array}{l}33.7 \\
28.0\end{array}$ & $\begin{array}{l}3.3 \\
3.7\end{array}$ & $\begin{array}{l}17.0 \\
13.6\end{array}$ & $\begin{array}{l}38.4 \\
46.3\end{array}$ & $\begin{array}{l}7.6 \\
8.4\end{array}$ \\
\hline Mean & $\stackrel{A}{S V}$ & $\begin{array}{l}0.0322 \\
0.0454\end{array}$ & $\begin{array}{l}29.5 \\
26.7\end{array}$ & $\begin{array}{l}3.2 \\
4.0\end{array}$ & $\begin{array}{l}14.7 \\
12.5\end{array}$ & $\begin{array}{l}41.2 \\
45.7\end{array}$ & $\begin{array}{l}11.4 \\
11.1\end{array}$ \\
\hline
\end{tabular}

* Expressed in per cent by weight of the sum of the methyl esters of the 5 determined fatty acids.

$\dagger \mathrm{A}=$ arterial; $\mathrm{SV}=$ saphenous vein. 


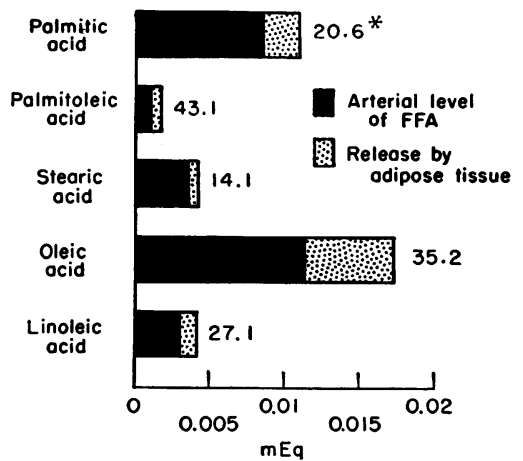

Fig. 2. Release of individual FFA by subcutaneoUS ADIPOSE TISSUE IN DOG. The total length of the bars represents the saphenous venous, and the dark portion the arterial level of individual FFA, expressed in $\mathrm{mEq}$ per $100 \mathrm{ml}$ plasma. The stippled portion of the bars corresponds to the release by adipose tissue. Each figure* represents the percentage release of an individual FFA. (Mean values obtained from four dogs.)

acids. The release of individual FFA by fat depots is graphically illustrated in Figure 2 . It is seen that 43.1 per cent of the free palmitoleic acid and 35.2 per cent of the free oleic acid present in saphenous vein plasma were released by adipose tissue; only 20.6 and 14.1 per cent of the free palmitic and stearic acids, respectively, were released.

\section{DISCUSSION}

The values for total FFA in plasma agree with those published by Gordon and his associates (5) and with those previously obtained in this laboratory (1). A comparison of the composition of the FFA fractions obtained in this series with that found by Dole shows similar values for palmitic and palmitoleic acids. However, in the present series, the fractions of stearic and linoleic acids are lower, while the proportion of oleic acid is higher. This may well be due to differences in subjects on whom these tests were performed. In the series of Dole and co-workers (9), determinations were made on fasting male medical students and on laboratory personnel. His subjects were healthy and of good dietary habits. In this series, although all patients were fasting for at least 12 hours, the subjects were chosen at random from the patients of a large municipal hospital. However, none of the patients studied in this series had any known metabolic disease.

As illustrated in Tables III and IV, the heart extracts considerable amounts of FFA. This is in line with previous publications from this laboratory (1) as well as with the data of Gordon and his associates (5) and of Olson (11). As illustrated in Tables III and IV, significant differences exist between the FFA composition of arterial and coronary sinus blood. The proportion of oleic acid in coronary sinus blood is lower than that in arterial blood, demonstrating a high degree of extraction (Figure 1). In both man and dog, the percentage of palmitic acid in coronary sinus blood is higher than that in arterial blood, and in the $\operatorname{dog}$ the proportion of stearic acid is also higher in coronary sinus blood, demonstrating a low rate of myocardial uptake. Thus, although the percentage of an individual FFA may be greater in coronary sinus than in arterial blood, the level of this FFA can still be lower as a result of its myocardial extraction (Figure 1).

These observations illustrate that the human as well as the dog heart extracts all individual FFA analyzed. However, there exist significant differences in the rate of myocardial uptake of individual FFA. This is indicated by the relatively larger percentage extraction of free oleic acid. Oleic acid is also released to a larger extent by subcutaneous adipose tissue. The percentage myocardial extraction of free palmitic and stearic acids as well as their release from adipose tissue is low (Figure 2). These observations suggest different turnover rates of individual FFA. However, definitive proof of this is lacking, since release of free fatty acids and their uptake has been investigated from two sites only, the subcutaneous fat and the heart.

Several possible explanations exist for the different rates of myocardial uptake of individual FFA as estimated by their coronary arteriovenous balances. In the first place, a preferential uptake of oleic acid by the heart muscle cell itself is a possibility. However, observations by Neptune, Sudduth, Foreman and Fash (12), obtained on striated muscle incubated in a medium containing different $\mathrm{C}^{14}$-labeled FFA, make this unlikely. These investigators measured the uptake and oxidation of free oleic acid and found it not to be higher than that of other FFA. Conversion of oleic acid to stearic acid by hydration must also be considered. This is unlikely since it has been shown that hydration of oleic acid appears not to 
take place in the animal organism (13). Since the amount of adipose tissue drained by the coronary sinus is much lower compared with that of heart muscle tissue, it is unlikely that FFA release by myocardial fat tissue influences markedly the FFA composition of coronary sinus blood.

It should be considered that the myocardial uptake of esterified fatty acids, which exceeds the myocardial extraction of FFA in the postabsorptive state (1), might influence the coronary arteriovenous balance of individual FFA. Plasma triglycerides play an important role in the fatty acid transport of the intact organism. They may enter the cells, as in the case of adipose tissue (14), after previous hydrolysis, apparently catalyzed by lipoprotein lipase (15), or they are taken up as triglycerides, as in the case of the liver $(16,17)$, which contains no lipoprotein lipase. High lipoprotein lipase activity has been demonstrated in rat heart muscle (18), and it appears, therefore, not unlikely that hydrolysis of plasma triglycerides by lipoprotein lipase preceds their uptake by the myocardium. Borgström (19) has demonstrated in vitro an exchange between plasma triglyceride fatty acids and FFA in the presence of lipoprotein lipase. In line with this concept are observations of Havel and Fredrickson (20) who showed in the intact $\operatorname{dog}$ that $\mathrm{C}^{14}$-labeled triglyceride fatty acids, when injected intravenously, reappear in the plasma FFA fraction. Thus, the FFA in coronary sinus blood could partly originate from hydrolysis of plasma triglycerides through the action of lipoprotein lipase and may therefore have a different composition from the FFA in arterial blood. Finally, an exchange of FFA with other esterified fatty acids, such as phospholipid fatty acids, might also account for some of the coronary arteriovenous difference of the FFA composition.

\section{SUMMARY}

The myocardial extraction of individual free fatty acids (FFA) and their release by subcutaneous adipose tissue was investigated in man and dog.

In the postabsorptive state, the human as well as the dog heart extracted a consistently higher percentage of free oleic acid than of any other FFA present in arterial blood. This acid was also re- leased at a higher rate by fat depots of the dog. These findings suggest a high turnover rate of free oleic acid.

Several possibilities were examined to explain the high myocardial extraction of free oleic acid. It appears likely that an exchange between plasma triglycerides and free fatty acids in heart muscle, resulting from lipoprotein lipase activity, may be responsible.

\section{REFERENCES}

1. Ballard, F. B., Danforth, W. H., Naegle, S., and Bing, R. J. Myocardial metabolism of fatty acids. J. clin. Invest. 1960, 39, 717.

2. Fredrickson, D. S., Gordon, R. S., Jr. The metabolism of albumin bound $\mathrm{C}^{14}$-labeled unesterified fatty acids in normal human subjects. J. clin. Invest. 1958, 37, 1504.

3. Bates, M. W., and Olson, R. E. Turnover rates of nonesterified fatty acids in the postabsorptive dog. Fed. Proc. 1960, 19, 230.

4. Bing, R. J., Vandam, L. D., Gregoire, F., Handelsman, J. C., Goodale, W. T., and Eckenhoff, J. E. Catheterization of coronary sinus and middle cardiac vein in man. Proc. Soc. exp. Biol. (N. Y.) 1947, 66, 239.

5. Gordon, R. S., Jr., Cherkes, A., and Gates, H. Unesterified fatty acid in human blood plasma. II. The transport function of unesterified fatty acid. J. clin. Invest. 1957, 36, 810.

6. Hallgren, B., Stenhagen, S., Svanborg, A., and Svennerholm, L. Gas chromatographic analysis of the fatty acid composition of the plasma lipids in normal and diabetic subjects. J. clin. Invest. 1960, 39, 1424.

7. Lovelock, J. E. A sensitive detector for gas chromatography. J. Chromatog. 1958, 1, 35.

8. Lipsky, S. R., and Landowne, R. A. A new partition agent for use in the rapid separation of fatty acid esters by gas-liquid chromatography. Biochim. biophys. Acta 1958, 27, 666.

9. Dole, V. P., James, A. T., Webb, J. P. W., Rizack, M. A., and Sturman, M. F. The fatty acid patterns of plasma lipids during alimentary lipemia. J. clin. Invest. 1959, 38, 1544.

10. Hohenleitner, F. J. Thesis (Hahnemann Medical College, 1960) cited by B. Issekutz, Jr., and J. J. Spitzer in Uptake of free fatty acids by skeletal muscle during stimulation. Proc. Soc. exp. Biol. (N. Y.) 1960, 105, 21.

11. Olson, R. E. Myocardial metabolism in congestive heart failure. J. chron. Dis. 1959, 9, 442.

12. Neptune, E. M., Jr., Sudduth, H. C., Foreman, D. R., and Fash, F. J. Phospholipid and triglyceride metabolism of excised rat diaphragm and the role of these lipids in fatty acid uptake and oxidation. J. Lip. Res. 1960, 1, 229. 
13. Bernhard, K., Rothlin, M., and Wagner, H. Zur Frage der Hydrierung ungesaettigter Fettsaeuren im Tierkoerper. Helv. chim. Acta 1958, 41, 1155.

14. Reiser, R., Williams, M. C., and Sorrels, M. F. The transport and dynamic state of exogenous glycerol- and palmitic acid-labeled tripalmitin. J. Lip. Res. 1960, 1, 241.

15. Robinson, D. S., and French, J. E. Heparin, the clearing factor lipase, and fat transport. Pharmacol. Rev. 1960, 12, 241.

16. Borgström, B., and Jordan, P. Metabolism of chylomicron glyceride as studied by $\mathrm{C}^{16}$-glycerol- $\mathrm{C}^{14}$ palmitic acid labeled chylomicrons. Acta Soc. Med. upsalien. 1959, 64, 185.
17. Stein, Y., and Shapiro, B. Uptake and metabolism of triglycerides by the rat liver. J. Lip. Res. 1960, 1, 326.

18. Korn, E. D., and Quigley, T. W., Jr. Studies on lipoprotein lipase of rat heart and adipose tissue. Biochim. biophys. Acta 1955, 18, 143.

19. Borgström, B. in Chemistry of Lipides as Related to Atherosclerosis, I. H. Page, Ed. Springfield, Ill., Charles C Thomas, 1958, p. 186.

20. Havel, R. J., and Fredrickson, D. S. The metabolism of chylomicra. I. The removal of palmitic acid 1-C $\mathrm{C}^{16}$ labeled chylomicra from dog plasma. J. clin. Invest. 1956, 35, 1025.

\section{Correction Notice}

The values listed for carbon dioxide content of the anemic subjects in the article by Sproule, Mitchell and Miller, "Cardiopulmonary Physiological Responses to Heavy Exercise in Patients with Anemia," which appeared in the February issue of this JournaL, 1960, 39, 378, were determinations of whole blood carbon dioxide content. Values listed for the carbon dioxide content of normal individuals, which appeared in the same article, were determinations of plasma carbon dioxide content. 